\title{
Financial Performance and the Quality of Sustainability Disclosure Based on Global Reporting Initiative: Value Relevances Study in Indonesia Stock Exchange
}

\author{
Wiwik Utami \\ Mercu Buana University; wiwik@mercubuana.ac.id; wiwikutami@gmail.com
}

Doi:10.5901/mjss.2015.v6n5s5p243

\begin{abstract}
The purpose of this study is to examine the influence of leverage, profitability, and the quality of sustainability disclosures on firm value with revenues growth as moderating variable. The quality of sustainability was measured based on disclosure index and the firm's value was measured using Tobin's Q. It examines firms companies in manufacturing industries listed in Indonesian Stock Exchange. Selected firm must have sustainability report in its financial reports of 2011-2013. A total of 143 firm years were examined using multiple regression. The results showed that leverage and profitability have positive significant influence on firm value. In addition, the study found that revenues growth was a moderating variable of the relationship between the quality of corporate sustainability disclosure and firm value.
\end{abstract}

Keywords: firm value, sustainability disclosure, leverage, profitability, revenues growth.

\section{Introduction}

The annual report is one of information picturing corporate performance in certain period. This information is provided by the management to the stakeholders. There are two type of information, the quantitative and qualitative. Financial report is quantitative information, mainly profitability and leverage is very interested for investor. Profitability is a proxy of future firm prospect and leverage is a proxy of future firm risk. Expectation of future firm's prospect and risk will impact on volatility of stock prices.

Lately investors are no longer thinks about how to create products and services to achieve the maximum profit, but beyond that the company should focus on the long term goal by taking into account the interest of stakeholders. One of the most interesting issues is global warming. Stakeholders in the world had realized that global warming will affect the planet's surface and climate change. As a response of global warming, management should take care towards sustainable development in all their business decisions. The firm's activity should be well managed to reduce $\mathrm{CO} 2$ emissions into the air.

The Global Reporting Initiative (GRI), located in the Netherlands has developed what is currently considered the "common framework for sustainability reporting". For the first time in June 2000, the GRI issued a set of Sustainability Reporting guide which contained reporting principles and specific content indicators. Next in 2006 GRI issued a new version to guide preparation of sustainability reports called G3 (third generation) and the latest is fourth generation that will be effective applied in 2015. By implementing GRI guidelines, corporations show a strong commitment of continuous improvement of their sustainability reporting practices.

Usually management uses corporate social responsibility (CSR) reporting to reveal the sustainability performance. The concept of social responsibility as a group of related issues, including human rights, human development and environmental protection issues. MacMillan et al. (2004) refer that the terms corporate social responsibility, corporate social performance and corporate social responsiveness have been used interchangeably. The Chartered Institute of Personal and Development prefers to use corporate responsibility (CR) terminology which will include social, environmental, and financial issues as well as legal compliance.

Management have primary goal to maintain legitimacy and to avoid bad publicity by implementing CSR (Runhaar and Lafferty: 2009). CSR drivers typically mentioned in literature are meant to inform shareholders and employees (Hemingway and Maclagan: 2004). Other important CSR drivers are anticipated cost savings and resulting innovations and learning (Lankoski 2008). Integrating CSR into corporate strategies will be able to improve the long-term performance and reduce risk.

Dilling (2010) contends that there is no globally accepted definition of CSR or sustainability reporting. The European Commission (2006) defines CSR as "a concept whereby companies integrate social and environmental 
concerns in their business operations and in their interaction with stakeholders on a voluntary". Similarly, there is neither a single globally accepted definition of sustainability reporting format nor a commonly accepted sustainability reporting that should follow.

Dhaliwal et al. (2012) examine the relationship between disclosure of nonfinancial information and analyst forecast accuracy using firm-level data from 31 countries. The research uses the issuance of stand-alone corporate social responsibility (CSR) reports to proxy for disclosure of nonfinancial information. The results show that the issuance of stand-alone CSR reports is associated with lower analyst forecast error. In the countries which more stakeholders oriented has stronger relationship between CSR and firm financial performance.

Indonesian capital market is considered as an emerging market. Implementation of CSR reporting in Indonesia is seemed to be in its infancy. There is award for listed companies who participate in sustainability reporting called Indonesia Sustainability Reporting Award (ISRA). The award has been held since 2005 and the growth of participants is relatively low regards to total listed company in Indonesia in 2014 are 436 companies (see graph 1). It means that the implementation of sustainability reporting in Indonesia is still in voluntary stage.

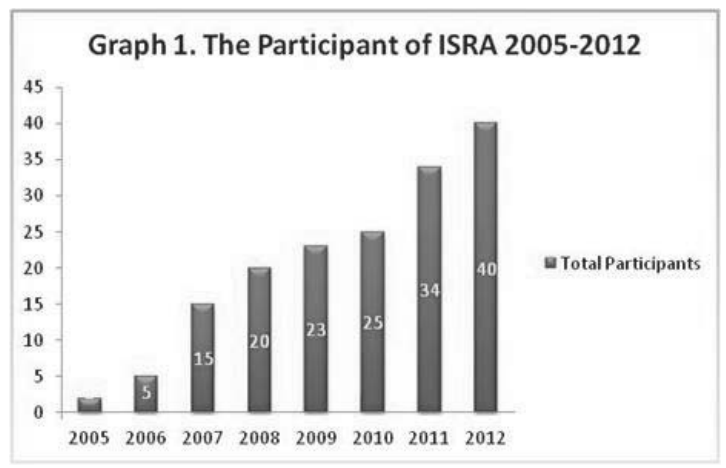

Figure 1: The Participant of ISRA

Source: ISRA reporting 2013

Value relevance study aims to test weather accounting information has association with stock prices movement. If capital market is efficient, share prices are reflect fully and quickly any new information, including accounting information and the quality of sustainability reporting. New information causes market participation to revise their expectations of future cash flows and their response will cause the price changes.

Dowell et al. (2000) found that studies on the financial performance and the quality of sustainability reporting affecting the firm value have generated consistent results in multinational enterprises in USA and Europe, but shown mixed results in developed and emerging countries. Some studies used the financial performance which include company size, the level of leverage, profitability, and ownership. Budiman and Supatmi (2009) examined the effect of the announcement of Indonesia Sustainability Reporting Award (ISRA) on the abnormal returns and trading volume of stocks in Indonesia Stock Exchange and showed that there is a change of abnormal returns around the announcement date of the award, but not significance change in terms of transaction volume.

The purposes of this study are twofold, (1) to assess the disclosure quality of the sustainability report using GRI indicators, and (2) to find out the relevance value of financial and sustainability performance on manufacturing listed companies. Benefits of the research are to provide a reference for practitioners on the application of corporate sustainability report and a reference for academics to the development a social accounting.

\section{Literature Review and Hypotheses}

\subsection{Sustainability Reporting}

In practice, the application of CSR in businesses is based on various approaches, i.e., community based development approach, philanthropy approach, or integrated strategy approach, creating shared value approach, and benchmarking 
approach (Saether et al., 2008; Habisch et al., 2005). This research used creating shared value approach. This approach was based on the idea that corporate success and social welfare are intertwines creating share value on companies. It is expected that with a good CSR performance the company will be superior.

The theory used in the study of disclosure practices in financial and non financial reporting was developed by Gray et al. (1995) which covers: (1) decision usefulness theory, (2) economic theory, and (3) social and political theory. The decision usefulness theory considers environmental aspects of corporate responsibility in the context of environmental accounting related to the interests of rational decision-making of investors and creditors. Interests of the investors are the maximization of value reflected in the company's value or stock prices.

In social and political theory, there are several theories, namely stakeholder theory, organizational legitimacy theory, political and economic theory. The theory assumes that the existence of the company's stakeholders is determined by the stakeholders. Companies are trying to find justification of the stakeholders in the company's operations resulting in the greater tendency of companies to adapt themselves to the desires of their stakeholders.

Social accountability is also associated with social contract theory. According to this theory, among the company's business and the community, there is implicit or explicit social contract. In social contract, social accounting is used as a set of techniques of data collection and disclosures, thus allowing the public to evaluate the social performance of organizations in their evaluation of the feasibility of operation of the organization (Parker, 2002).

In the standard GRI (3 $3^{\text {rd }}$ generation), performance indicators are divided into six main components, namely economic, environmental and social concerns of human rights, labor practices and working environment, and product responsibility and society. Total indicator are 79 items, comprising 9 economic indicators, 30 environmental indicators, 14 indicators of labor practices, 9 indicators of human rights, 8 social indicators, and 9 indicators of product liability.

\subsection{The Quality of Sustainability Reporting and Firm value}

Today more companies are already making an annual report that includes audited Sustainable Development and CSR issues such as the "triple bottom line reports", but reports vary greatly both in format, style and methodology of assessment even for the same industry. The sustainability report is provided by management to the shareholders. Management performance has an impact on liquidity and volatility of stock prices. Vilanova et al. (2009) explore the nature of the relationship between CSR and competitiveness. According to Vilanola et al. (2009), CSR and competitiveness relate through learning and innovation cycle, where corporate value, policies and practices are permanently defined and redefined. Learning takes place as CSR is embedded in business processes, and once it has been integrated, in turn, it generates innovative practice, and finally, competitiveness. Most studies on the relationship between competitiveness and CSR tried to prove that there is a positive association between CSR and financial performance (Griffin and Mahon,1997; McWilliams and Siegel 2001), although the result are inconclusive (Chand and Fraser, 2006).

Cohen et al. (2011) examined the public voluntary disclosure of a set of leading indicators of economic performance and sustainability of earnings provided using a sample of 50 publicly traded firms across five industries. The results indicate that, among the sample firms, there remains a lack of rigorous and expansive disclosure of this type of information and that considerable variability exists in disclosure practice based on both industry and size. The most frequent types of disclosures being concerned with information pertaining to market share and innovation.

Henri and Ane (2013) studied the relationship of corporate social responsibility (CSR) and firm value by considering customer awareness. The results showed that there is positive relationship for firms with high customer awareness, as proxy by advertising expenditures. For firms with low customer awareness, the relation is either negative or insignificant. This evidence is consistent with the view that CSR activities can add value to the firm but only under certain conditions.

\subsection{Financial Performance and Firm Value}

Financial leverage is the ratio of funds used to finance the company or the ratio between the funds obtained from external companies (creditors) and funds provided by the owner of the company. The ratio is used to provide an overview of the company's capital structure, so it can picture the level of risk is not a debt-collection. Therefore, companies with high leverage ratios have obligation to perform wider than companies with lower leverage ratios.

Leverage is divided into two measures, namely operating leverage and financial leverage. According to Brigham and Houston (2006:12), operating leverage is the extent to which fixed costs are used in the operation of a company. While financial leverage is the extent to which fixed income securities (debt and preferred stock) are used in a company's 
capital structure. Leverage has negative effect on firms value, because the higher leverage means higher risk that make investor change their expectation. However, investors may have positive perception because debt has an advantage view related to tax saving.

Profitability is commonly used as a proxy for management achievement in generating income and enhances shareholder value. The assessment of profitability is used to evaluate the efficiency of the corporate operation and to assist decision-making concerned with investment by investor. Return on asset, return on investment are usually used as proxy of profitability.

The annual report can be viewed as a gracious effort to reduce the information asymmetry between management and owners. There are potential conflicts of interest between management and owner. Management used his superiority of their information to make maximum benefits on their interest and disregard owner interest. Income is a bottom line of financial reporting. This accounting numbers is very interesting for investor because it is regarded as a good proxy for future cash flow. Profitability ratios measure a company's ability to generate profits. Wyatt (2008) stated that a large number of financial and nonfinancial information is value-relevant, and it is difficult to make categorical judgments about most other items, as differences in value-relevance could be due to different relevance or reliability, or both.

The value of the company describes the prospect of the company in the future. The objective of establishing the company is to increase the value of the company. The increasing value of the company that is easily visible from an external company are assets and stock market growth. Measurement of the value of the company is often done by using ratio or the ratio of market valuation. This study uses Tobin's $Q$ ratio as an indicator of firm value. This ratio was developed by Tobin (1967). James Tobin is an American economist who won the Nobel Prize in economics proposing hypothesis that the market value of a company should be equal to the replacement cost of the assets of the company so as creating a state of equilibrium. Tobin's $Q$ is the ratio of the market value of a firm's assets (as measured by the market value of the market value of it is outstanding stock and debt) to the replacement cost of the firm's assets.

Henri and Ane (2013) said that CSR activities can add value to the firm but only under certain conditions. I assume that business growth is one of condition that will promote firm value. The company who has high growth revenues will have opportunities to provide high profitability in the future and cash flow. To find out whether leverage levels, profitability and the quality of sustainability disclosures influence the firm value with revenues growth as moderating variable, the following hypotheses are formulated:

$\mathrm{H} 1$ : leverage influences firm value with revenues growth as moderating variable

$\mathrm{H} 2$ : Profitability influences firm value with revenues growth as moderating variable

H3: The quality of sustainability disclosures influences firm value with revenues growth as moderating variable.

\section{Research Methodology}

This study is causal based study. Population of the study is manufacturing companies listed in Indonesia Stock Exchange. The companies are selected using purposive sampling, with the following criteria: (1) Company has sustainability disclosures in their annual reports in 2011- 2013 and (2) the financial report can be accessed via internet.

The disclosure quality of sustainability reporting is obtained from annual data disclosed by the company. In the standard GRI (2013), performance indicators are divided into some components, namely economic, environmental and social concerns of human rights, labor practices and working environment, and product responsibility and society. Total indicator are 79 items. If company discloses items in accordance with GRI indicators, it will be scored of 1 , while the companies are not disclosed of GRI item given a score of 0 (zero). This study uses return on asset (ROA) as a proxy for profitability and financial leverage (debt to equity ratio) as a proxy of risk. Revenues growth was selected as moderating variable with regard to business growth.

The dependent variable is firm value measured using Tobin's $Q$ ratio. If the $Q$ ratio is above one, it indicates that the investment in assets to generate profits provides higher value of the investment expenditure, and it will stimulate new investment. If Tobin's $Q$ ratio below one, investing in assets is not attractive. The Tobin's $Q$ is measured using the following formula.

$$
Q=\frac{(E M V+D E B T)}{(T A)}
$$

where:

$\mathrm{Q}=$ value of the company; EMV = Equity market value (EMV = closing price $\mathrm{x}$ number of shares outstanding); $\mathrm{DEBT}=$ Total debt companies; $\mathrm{TA}=$ Total assets 


\section{Results and Discussion}

The research has collected 152 firm year data. The first step is reviewing the distribution of the data and eliminate outlier data. The next step is testing for all requirement to find goodness of fit of regression model. Final data consist of 143 firm years. Mean score of all research variable is presented in Table 1.

Table 1. Mean Score Variables 2011-2013

\begin{tabular}{llll}
\hline Variable & $\mathbf{2 0 1 1}$ & $\mathbf{2 0 1 2}$ & $\mathbf{2 0 1 3}$ \\
\hline Leverage (DER) & 2.172 & 1.183 & 1.543 \\
Profit (ROA) & 0.090 & 0.094 & 0.056 \\
Growth & 0.146 & 0.205 & 0.086 \\
Tobin's Q & 2.002 & 2.442 & 1.914 \\
GRI Quality & 0.151 & 0.165 & 0.205 \\
\hline
\end{tabular}

Table 1 shows that leverage tends to decrease from 2.172 in 2011 to 1.543 in 2013. It means that management prefer to cover his investment by issuing debt. The Profitability (ROA) is $9 \%$ in 2011 and the figure decreases in 2013 to be $5.16 \%$. Tobin's $Q$ ratio is more than 1 , it means that companies has a good investment performance. The best financial performance takes place in 2012 and the worst take place in 2013. The average quality of sustainable disclosures tends to increase. Index disclosure is $15.1 \%$ in $2011,16.6 \%$ in 2012 and increases to $20.5 \%$ in 2013 . The financial performance in 2013 decreases, but the quality sustainability disclosures is better. It means that management has better commitment to applied CSR issues. Table 2 present the result of hypothesis testing based on regression model output.

Table 2. Results of Regression Analysis

\begin{tabular}{lccc}
\hline Variable & Unstandardized Coefficients & Standardized Coefficients & Sig. Value \\
\hline Leverage & 0.393 & 0.217 & 0.344 \\
Profitability & 3.404 & 0.528 & 0.000 \\
GRI quality & -0.314 & -0.380 & 0.557 \\
Le Leverage-Growth & 0.011 & 0.171 & 0.038 \\
Le Profit-Growth & 8.480 & 0.390 & 0.000 \\
Le GRI -Growth & 2.383 & 0.144 & 0.038 \\
\hline \multicolumn{4}{r}{} \\
\hline
\end{tabular}

Table 2 shows that the coefficient of determination (Adj. $\mathrm{R}^{2}$ ) is $47.8 \%$, which means that $47.8 \%$ firm value can be explained by independent variables. The t-test values show that leverage and profitability have significant influence on the firm value but GRI quality disclosure is not significance. This findings mean that financial performance has relevance value and consistent with Wyatt (2008) who contended that financial information is value-relevant. Revenues growth not moderate the relationship between financial performance and firm value, this finding indicate that financial performance is dominant information for investor decision. Leverage coefficient is positive which means that companies with greater leverage have more opportunity to create value.

The quality of sustainability disclosure does not have significance influence on firm value. Revenue growth has role as moderating variable that makes the relationship between quality of sustainability disclosure and firm value is stronger. This finding is consistent with Henri and Ane (2013) who stated that CSR activities can add value to the firm but only under certain conditions. It means that a company that has higher quality sustainability disclosure would increase firm value if the revenue growth is higher. The benefit of GRI implementation is not in the short time but in the long run. Consequently, investor who has short time investment orientation may not consider information related to GRI.

\section{Conclusion}

The study was carried out in order to determine the effect leverage, profitability and the quality of sustainability disclosure on firm value. Results indicate that leverage has positive and significant effect on firm value, profitability has positive and significant effect on the firm value, and revenue growth is a moderating variable of the relationship between the quality of corporate sustainability disclosure and firm value.

The limitation of the study relates to the size of the sample firms. This study examined 143 firm years covering 
three years of observation, making the results are not generalizable to other companies with different characteristics. Future study may observe more sample years and used GRI fourth indicators.

\section{References}

Brigham, E. F. \& Joel F. Houston. (2006). Fundamentals of Financial Management. Book 2, Issue 10. Singapore: McGraw-Hill

Chand, M. and S. Fraser. (2006). The relationship between corporate social performance and corporate Financial Performance: Industry type as Boundary condition, Business Review, Cambridge 5(!), 240-245

Cohen Jeffref., Holder-Webb Lori L., Nath Leda., \& Wood David. (2012). Corporate

Reporting of Nonfinancial Leading Indicators of Economic Performance and Sustainability. Accounting Horizons, Vol.26, No.1 pp 65-90.

Dhaliwal and S., Radhakrishnan Suresh., Tsang Albert., \& Yang Yong George. (2012).

Nonfinancial Disclosure and Analyst Forecast Accuracy: International Evidence on Corporate Social Responsibility Disclosure. The Accounting Review, Vol. 87, No.3 pp 723-759.

Dilling, Petra F A. (2010). Sustainability Reporting In A Global Context: What Are The Characteristics Of Corporations That Provide High Quality Sustainability Reports - An Empirical Analysis, The international Business \& Economics, Research Journal 9.1: 19-30

Dowell, G., Hart, S. and Yeung, B. (2000). Do Corporate Global Environmental standard

Create or Destroy Market Value? Management Science,Vol. 46 No. 8, pp. 1059-1074

Francisca van Dijken. (2007). Corporate social responsibility: Market regulation and Evidence, Managerial Law 49. 4: 141-184

Gray, R., Kouhy, R., Lavers, S. (1995). Corporate social and environmental reporting: a

review of the literature and a longitudinal study of UK disclosure. Account. Audit. Acc. J. 8, 47

Griffin.J and J.Mahon.(1997). The corporate social performance and corporate Financial Performance Debate: Twenty Five Years of incomparable Research, Journal of Business and Society 36 (1), 5-31

Habish, Andre, Jan jonker, Martina Wegner, Schmidpeter, R. (2005). "Corporate Social Responsibility Across the Europe", Heildelberg, Springer

Haigh, Matthew. (2006). The Drivers of Corporate Social Responsibility: A Critical Review. The Business Review. Cambridge 5.2, 245251

Hemingway, C. \& Maclagan, P. (2004). Managers' Personal Values as Drivers of Corporate Social Responsibility. Journal of Business Ethics 50, no. 1 (March 1, 2004): 33-44. <http://www.proquest.com.arktos.nvit.edul

Henri Servaes , T. Ane. (2013). The Impact of Corporate Social Responsibility on Firm

Value: The Role of Customer Awareness. Institute for Operations Research and the management Sciences, Vol.59 pp 1045-1061

Lankoski, L. 2008. Corporate responsibility activities and economic performance: a theory of why and how they are connected. Business Strategy and the Environment. 17, no. 8 (December 1, 2008): 547.

Macmillan, K., Money, K., Downing, S. and Hillenbrand, C. (2004). "Giving your organisation SPIRIT: an overview and call to action for directors on issues of corporate governance, corporate reputation and corporate responsibility", Journal of General Management, Vol. 30 No. 2, Winter, pp. 15-42.

McWilliams, A and Siegel. (2001). Corporate social responsibility: A Theory of Firm Perspective. Academy of Management Review 26 (1), $117-128$

Runhaar, H. \& Lafferty, H. (2009). Governing Corporate Social Responsibility: An Assessment of the Contribution of the UN Global Compact to CSR Strategies in the Telecommunications Industry. Journal of Business Ethics 84, no. 4: 479-495. Business Source Complete

Saether, Kim T; Ruth V Aguilera. (2008). Corporate Social Responsibility in a Comparative Perspective, (http:/www.business.uiic.edu/ Aguilera)

Stanny, E. \& Ely, K. (2008). Corporate environmental disclosures about the effects of climate change. Corporate Social Responsibility \& Environmental Management 15, no. 6 (November 2008): 338-348

The Commission To The European Parliament, The Council And The European Economic And Social Committee. (2006). Implementing the partnership for growth and jobs: making Europe a pole of excellence on corporate social responsibility

Vilanova, M., M. J.Lozano and D. Arenas. (2009). Exploring the Nature of the Relationship

Between CSR and Competitiveness. Journal of Business Ethics 87:57-69

Wyatt Anne. (2008). What financial and non-financial information on intangibles is value - relevant? A review of the evidence. Accounting and Business Research, Vol. 38, No.3 pp 217-256 